Dorota Pietrzkiewicz

Warszawa

\title{
Profesor Tadeusz M. Nowak (1917-2010) i jego działalność na polu edytorstwa źródeł historycznych ${ }^{1}$
}

28 maja 2010 roku zmarł prof. dr hab. Tadeusz Marian Nowak - nestor polskiej historii wojskowości, kartograf, wydawca rękopisów i starych druków dotyczących militariów, ekspert „Wielkiej Gry”2, wieloletni redaktor „Studiów i Materiałów do Historii Wojskowości” i „Kwartalnika Historii Nauki i Techniki”. Miałam zaszczyt współpracować z nim, uczyć się warsztatu, a także przyjaźnić. Profesor należał do grupy uczonych perfekcjonistów - dbających o każdy szczegół przekazywanego do druku tekstu, prowadził rzetelne kwerendy i badania, posługiwał się nienaganną polszczyzną oraz wyrażał chęć bezinteresownej koleżeńskiej pomocy. Był erudytą, poliglotą i niespotykanie pracowitym badaczem. Praca naukowa była dla niego pasją. Doskonale godził tę pasję z życiem rodzinnym. Wolne chwile poświęcał turystyce pieszej, zwłaszcza górskiej, uprawianej wraz z żoną Janiną Nowakową (1918-1993), oraz tworzeniu dla niej misternej biżuterii srebrnej. Precjoza te oparte były na wzorach średniowiecznych rozet gotyckich zdobiących katedry francuskie i hiszpańskie, na elementach sztuki egipskiej oraz, podobnych jak u Stanisława Wyspiańskiego, stylizacjach florystycznych. Pasjonowała go fotografia oraz sztuki plastyczne. Przez wiele lat rzeźbił postacie ludzkie, zwierzęce i różne fantasmagorie, malował krajobrazy. $Z$ aparatem fotograficznym nie rozstawał się od 14 roku życia. $\mathrm{Z}$ zamiłowaniem fotografował

${ }^{1} \mathrm{Na}$ temat rękopisów i starych druków w pracach prof. dr. hab. Tadeusza Mariana Nowaka pisałam w 44. jubileuszowym tomie „Studiów i Materiałów do Historii Wojskowości” (dalej SMHW) wydawanym przez Ośrodek Badań Historii Wojskowej Muzeum Wojska w Białymstoku. Zob. D. Pietrzkiewicz, Rękopisy i stare druki w życiu i pracach profesora Tadeusza Mariana Nowaka, „SMHW”, 44:2007, s. 41-49.

2 T.M. Nowak, Moja przygoda $z$ Wielka Gra. Fragment pamiętnika, „Analecta. Studia i Materiały z Dziejów Nauki”, 18:2009, z. 1-2, s. 367-404 . 
chmury, drzewa, kwiaty czy pisanki malowane przez panią Janinę Nowakową. Ostatnio robił zdjęcia ukochanemu prawnuczkowi, niespełna trzyletniemu Patrykowi. Jego pasja fotograficzna została raz zaprezentowana szerszemu gronu podczas wystawy zorganizowanej w Centralnej Bibliotece Wojskowej, której tematem były warszawskie parki i ogrody oraz znajdujące się w nich pomniki.

W pracy naukowej dużo miejsca poświęcił publikacji źródeł do dziejów polskiej i europejskiej inżynierii i techniki wojskowej, m.in. pióra Jana Tarnowskiego (1488-1561), Albrechta Starszego Brandenburga (1490-1568), Andrzeja dell'Aquy (1584-1656), Kazimierza Siemienowicza (ok. 1600-ok.1651), Józefa Narońskiego (ok. 1610-1678), Józefa Bema (1794-1850), oraz krytycznemu wydaniu źródeł ikonograficznych i kartograficznych - przechowywanych w zbiorach szwedzkich - dotyczących dziejów artylerii polskiej XVI-XVIII wieku, a także historii wojen polsko-szwedzkich. Posiadał zmysł bibliologa. Miał świadomość tego, że dla stworzenia szerszego dostępu do materiałów źródłowych, a także dla ich zabezpieczenia i ochrony, niezbędne jest podejmowanie prac związanych $\mathrm{z}$ ich publikacją. W jego działalności naukowej przebiegało to w dwojaki sposób. $Z$ jednej strony wydawał opracowania i monografie, z drugiej zaś edycje krytyczne konkretnych materiałów źródłowych. Przeprowadzał tak zewnętrzną erudycyjną krytykę źródła (w odniesieniu do obiektu bibliotecznego), jak krytykę wewnętrzną - podejmowaną tylko w ramach swojej specjalności historii i historii wojskowości.

Tadeusz Marian Nowak urodził się w Krakowie 24 czerwca 1917 roku w rodzinie o tradycjach lekarskich i inżynierskich. Inżynierami byli jego dwaj dziadkowie: Karol Nowak (ze strony ojca), dyrektor fabryki tytoniu w Krakowie, Marian Kwiatkowski ${ }^{3}$ (ze strony matki), absolwent politechniki monachijskiej, a także jego ojciec - Rudolf Nowak, nauczyciel elektrotechniki w Wyższej Szkole Przemysłowej w Bielsku na Śląsku, a później pomysłodawca i organizator technicznych szkół średnich w Dębicy, Nowym Bytomiu i Sosnowcu, oraz trzej stryjowie. Decyzję o uprawianiu nauki podjął jeszcze we wczesnej młodości, którą spędził na Śląsku. Wspominał: „Wszystko rozpoczęło się od domu rodzinnego, typowego inteligenckiego: pradziadek lekarz, obaj dziadkowie - inżynierowie, ojciec również inżynier, matka - biolog. Mieszkające z nami babcie: matka mojej matki, władająca - po wychowaniu i nauce tylko domowej - językiem łacińskim, francuskim i rosyjskim i jej siostra, która [...]

${ }^{3}$ T.M. Nowak, O moim dziadku Marianie Kwiatkowskim. Fragment pamiętnika, „Analecta...”, 12:2003, z. 1-2, s. 253-263. 
uczyła w Bielsku na Śląsku miejscowych Niemców języków polskiego i rosyjskiego, a domowe dzieci, między innymi mnie - francuskiego. Moja matka dobrze pamiętała $\mathrm{z}$ nauki w krakowskim żeńskim gimnazjum klasycznym grekę i łacinę, a ze swą matką i ciotką rozmawiała chętnie po francusku, z mężem zaś po niemiecku"4.

Podczas nauki w ośmioletnim polskim gimnazjum humanistycznym w Bielsku Tadeusz Marian Nowak opanował biegle dwa języki: łaciński i niemiecki, a także zdobył podstawy matematyki, fizyki i chemii, co pozwoliło mu na zajęcie się w przyszłości historią techniki. Jego umiłowanym zajęciem było wtedy - jak wielokrotnie mi o tym opowiadal - rysowanie map, które doprowadziło go później do studiowania na Uniwersytecie Jagiellońskim, obok historii, kartografii i miernictwa. Rozpamiętywał: „Od czytania i pisania niedaleko do rysowania, a wśród znajdujących się w naszym domu książek moim szczególnym zainteresowaniem cieszyły się dwa atlasy Eugeniusza Romera: Geograficzno-statystyczny atlas Polski i Atlas geograficzny [...], a także polskie wydanie austriackiego atlasu Kozenna, który nazywaliśmy «atlasem korzennym». Z nich to próbowałem przerysowywać moje pierwsze mapki"5.

Jako kilkunastoletni młodzieniec zaczął samodzielnie zapoznawać się z hieroglifami egipskimi, babilońskim pismem klinowym i językiem akadyjskim, a przy sposobności i hebrajskim. W czerwcu 1935 roku zdał maturę i kierowany fascynacją starożytnym Wschodem zapisał się na Wydział Filozoficzny Uniwersytetu Jagiellońskiego. W Krakowie zamieszkał u Józefa Haydukiewicza (męża nieżyjącej już wówczas siostry jego matki), nauczyciela gimnazjalnego historii i geografii.

Wspominając gimnazjalne lata profesora Nowaka, przytoczę dwie anegdoty. Obydwie dotyczą książek, których lektura wpłynęła na wybór i charakter podjętej w przyszłości przez niego pracy. Będąc uczniem siódmej klasy gimnazjalnej, otrzymał od swojego wuja Zbigniewa Trylskiego - inżyniera rolnika, nauczyciela Szkoły Rolniczej w Białokrynicy należącej do Liceum Krzemienieckiego - niedużą książeczkę Stefana Rudniańskiego (1887-1941) pt. Technologia pracy umystowej ${ }^{6}$. Prezent ten znalazł praktyczne wykorzystanie i stał się przewodnikiem w metodach skutecznego i efektywnego prowadzenia warsztatu naukowego.

4 T.M. Nowak, Moja droga do pracy naukowej, „Przegląd Historyczno-Wojskowy. Kwartalnik" 2(217): 2007, s. 9.

5 T.M. Nowak, Kartografia - moja mitość. Fragment pamiętnika, „Analecta...”, 19:2010, z. 1-2, s. 273.

${ }^{6}$ S. Rudniański, Technologia pracy umystowej, Warszawa 1933. 
Profesor często z sentymentem wspominał mi o tym podarunku, który zajmował honorowe miejsce w jego bibliotece. Drugą książką był Kodeks karny, którego zakup poprzedziło wydarzenie tak opisane przez Profesora: „Gdy byłem - obok nauki szkolnej - bez reszty zajęty tak pasjonującymi zagadnieniami, przyjechał z Krakowa na jeden dzień starszy ode mnie o przeszło dwa lata mój brat cioteczny. Przybył po to, żeby mnie nakłonić do założenia w moim uczciwym gimnazjum tajnej komórki jakiejś organizacji. Dość ostro nalegał, ale w końcu pojechał do swojego Krakowa, a ja poszedłem do polskiej księgarni i kupiłem, chyba za złotówkę, małą książeczkę oprawną w czerwone płótno, noszącą tytuł Kodeks karny. Zanim doszedłem do domu, znalazłem w niej paragraf, mówiący jaka kara jest przewidziana za należenie do tajnej organizacji. A co dopiero za jej zakładanie! Zdecydowanie wolałem uczyć się moich hieroglifów. Nabrałem przy tym tak ogromnego wstrętu do zajmowania się polityką, że aż do dziś trzymam się od niej z dala. Prawdopodobnie zostałem stworzony do uprawiana nauki, a nie polityki"

Tadeusz Marian Nowak studiując w latach 1935-1939 na Uniwersytecie Jagiellońskim historię ${ }^{8}$ równocześnie kartografię ${ }^{9}$, porównawcze językoznawstwo indoeuropejskie ${ }^{10}$ oraz języki semickie ${ }^{11}$, a później będąc na tymże uniwersytecie w latach 1945-1948 młodszym asystentem na Katedrze Historii Starożytnej profesora Ludwika Piotrowicza, a w latach 1948-1951 starszym asystentem na Katedrze Historii Gospodarczej Polski Średniowiecznej profesora Romana Grodeckiego ${ }^{12}$, miał do czy-

7 T.M. Nowak, Moja droga do..., s. 10.

${ }^{8}$ Uczestniczyl w zajęciach prowadzonych przez profesorów, m.in.: Władysława Semkowicza, Ludwika Piotrowicza, Jana Dąbrowskiego, Romana Grodeckiego, Władysława Konopczyńskiego, Józefa Feldmana, Kazimierza Piwarskiego, Stanisława Kota.

${ }^{9}$ Kreślił mapy pod okiem profesora Stanisława Korbla i, natenczas adiunkta, Józefa Szaflarskiego. Korzystając z sugestii wykładowców brał także udział w wykładach i ćwiczeniach z miernictwa, prowadzonych na Wydziale Rolniczym Uniwersytetu Jagiellonskiego przez profesora Adama Rożańskiego. Wspominał: „Wykłady Korbla przepełnione były odstraszającą niektórych słuchaczy, a zwłaszcza słuchaczki - ale nie mnie - matematyką. Studium kartografii obejmowało zajęcia trwające przez cały rok akademicki, przy czym po każdym trymestrze zdawało się kolokwium. Obowiązywało ono studentów geografii, dla mnie zaś stanowiło rodzaj satysfakcjonującego sprawdzianu i uzyskania formalnego uznania przez specjalistę moich umiejętności w dziedzinie od dawna przeze mnie umiłowanej i praktycznie wykonywanej". Zob.: T. M. Nowak, Kartografia..., s. 277.

${ }^{10}$ Uczęszczał na seminarium z językoznawstwa indoeuropejskiego, które od 1935 roku prowadził Jan Safarewicz.

${ }^{11}$ Chodził na wykłady profesora Tadeusza Kowalskiego, księdza docenta Alfonsa Bielenina oraz doktora Benziona Katza.

${ }^{12}$ Będąc asystentem profesora Romana Grodeckiego, Tadeusz Marian Nowak zbierał materiały do pracy doktorskiej pt. Miasta matopolskie do 1506 roku. Zgromadzone informacje zaprezentował na dwóch mapach w skali 1:500.000, obejmujących podstawowe 
nienia $\mathrm{z}$ rękopisami, ale tylko średniowiecznymi na podstawowym i wyższym kursie paleografii oraz z nielicznymi, tylko dla przykładu pokazywanymi studentom, starymi drukami Biblioteki Jagiellońskiej. Warto tu nadmienić, że już od pierwszego roku studiów był zaangażowany w studenckie życie naukowe w Kole Historyków. Najpierw był pomocnikiem bibliotekarza, później bibliotekarzem, a wreszcie wiceprezesem do spraw naukowych Koła Historyków Uczniów Uniwersytetu Jagiellońskiego. Wówczas do jego obowiązków należało organizowanie odczytów i zebrań naukowych, kursów przygotowawczych do egzaminów z nauk pomocniczych historii i z historii starożytnej, opracowywanie planów studenckich wypraw naukowych oraz nadzór nad księgozbiorem.

Krakowski okres w życiu i działalności profesora Tadeusza Mariana Nowaka to również współpraca z redakcjami „Kwartalnika Historycznego”, „Roczników Dziejów Społecznych i Gospodarczych”, „Życia Nauki” i „Myśli Współczesnej”. Na łamach tych czasopism ukazywały się jego artykuły, recenzje i tłumaczenia prac z języków obcych.

Inaczej było w Warszawie, do której przeniósł się w 1951 roku. Jego służbowym zadaniem, jako sekretarza naukowego Komisji WojskowoHistorycznej MON (1951-1958), a później pracownika naukowego Wojskowego Instytutu Historycznego (1958-1991), było przede wszystkim organizowanie badań naukowych w dziedzinie dawnej historii wojska polskiego $^{13}$. Niezależnie od tej pracy Profesor rozwinął własną, intensywną ${ }^{14}$ działalność naukową w postaci badań dotyczących głównie dawnej (do końca XVIII wieku) historii techniki, najpierw polskiej, później przede wszystkim ogólnoeuropejskiej. Interesowały go zagadnienia z zakresu techniki wojskowej, którym poświęcona jest większość jego prac naukowych. Wymienię tu tylko Arsenaty artylerii koronnej w latach 1632-1655 oraz Polska technika wojenna XVI-XVIII wieku. Na podstawie pierwszej z nich uzyskał 3 marca 1970 roku na Wydziale Historycznym Uniwersytetu Warszawskiego stopień doktora nauk humanistycz-

wiadomości, czyli rozmieszczenie miast oraz czas ich lokalizacji, jak również - dodatkowe, bardziej szczególowe dane - uwzględniające drogi handlowe na terenie województw krakowskiego, sandomierskiego i lubelskiego (wchodzących w skład szesnastowiecznej Małopolski) z ukazaniem lokalizacji komór celnych oraz targów. Prace nad rozprawą doktorską przerwało jego służbowe przeniesienie do Warszawy.

${ }^{13} \mathrm{~J}$. Sikorski, $Z$ życia i działalności profesora Tadeusza Mariana Nowaka - w 65. rocznice urodzin, SMHW, 25:1982, s. 3-26; T.M. Nowak, $Z$ dziejów organizacji badań nad historia wojskowa w Polsce Ludowej, SMHW, 30:1988, s. 19-41.

${ }^{14}$ Bibliografia prac Profesora liczy ponad 300 pozycji. Zob. D. Pietrzkiewicz, Bibliografia opublikowanych prac prof. dra. hab. Tadeusza Mariana Nowaka 1947-2007, „Przegląd Historyczno-Wojskowy", 8(59):2007, nr 2 (217), s. 17-38. 
nych, druga zaś stanowiła podstawę nadania mu 21 marca 1974 roku przez Radę Naukową Zakładu Historii Nauki i Techniki Polskiej Akademii Nauk stopnia doktora habilitowanego nauk humanistycznych w zakresie historii techniki wojennej.

Ta własna, indywidualnie wybierana tematyka nie natrafiała na przeszkody jeśli chodzi o publikowanie wyników badań. Związana była $\mathrm{z}$ wykorzystywaniem - obok bardzo ważnych zabytków kultury materialnej (dawne uzbrojenie i budownictwo wojskowe, zwłaszcza fortyfikacyjne) przede wszystkim źródeł pisanych w postaci rękopisów i starych druków, gdyż, jak Profesor mawiał, „wyruszając na poszukiwanie początków, zawsze jesteśmy skłonni najpierw odczytać słowa, a dopiero za ich pośrednictwem docierać do istoty rzeczy".

Wykorzystując w swej pracy naukowej i rękopisy i druki wydane do 1800 roku, profesor Tadeusz Marian Nowak stał się ich miłośnikiem, sumiennym wydawcą oraz znawcą. Wertowanie rękopiśmiennych i drukowanych katalogów i inwentarzy, zarówno manuskryptów, jak i starych druków bibliotek polskich i zagranicznych, jak również zorganizowanie w Komisji Wojskowo-Historycznej MON, a później w Wojskowym Instytucie Historycznym, kwerendy rękopisów w dziesięciu bibliotekach i dziesięciu archiwach polskich znalazło wkrótce odbicie $w$ jego pracach opartych przede wszystkim na tym materiale źródłowym.

Nie sposób tu wymienić wszystkich prac Tadeusza Mariana Nowaka. Chciałabym jednak omówić te, które uważam - z różnych względów - za szczególnie interesujące. Najwcześniej, bo już w 1955 roku, ukazało się dokonane przez Profesora pełne wydanie dwóch opisów morskiej bitwy flot polskiej i szwedzkiej w dniu 28 listopada 1627 roku na wodach Zatoki Gdańskiej, znanej jako bitwa pod Oliwą ${ }^{15}$. Publikacja ta objęła zarówno faksymile oryginalnych druków z lat 1627 i 1628, ich transkrypcję z języków niemieckiego i holenderskiego, ich - dokonane przez Profesora - tłumaczenie na język polski, a także reprodukcję trzech sztychowanych obrazów bitwy.

Równocześnie profesor Tadeusz Marian Nowak rozpoczął pracę nad przygotowywaniem do druku cyklu czterech wielkich rękopisów z XVI i XVII wieku. Zadanie to trwało wiele lat i dało w wyniku opublikowanie każdego z nich. Najbardziej praco- i czasochłonny wysiłek polegał na stworzeniu maszynopisu zawierającego transkrypcję tekstu manuskryp-

${ }^{15}$ Praca ta opublikowana została jako aneks do książki Mariana Krwawicza redagowanej przez Tadeusza Mariana Nowaka. Zob. M. Krwawicz, Walki w obronie polskiego wybrzeża w roku 1627 i bitwa pod Oliwa, Warszawa 1955, s. 135-145. 
tu. Dalsze czynności polegały na napisaniu wstępu zawierającego trudny nieraz do odtworzenia życiorys autora, opisaniu losów publikowanego rękopisu, a także na opracowaniu szczegółowego komentarza zarówno tekstowego, jak i rzeczowego.

Praca wykonywana była - jak wspominał Profesor - w zaadaptowanej do tego celu kuchni jego jednopokojowego mieszkania w ten sposób, że jego żona mgr Janina Nowakowa ${ }^{16}$, mediewistka ${ }^{17}$ uważana przez profesora Władysława Semkowicza (1878-1949) za bardzo dobrą specjalistkę w dziedzinie paleografii, czytała głośno rękopis, a Profesor pisał jego tekst na maszynie. Praca ta trwała codziennie od godziny czwartej do siódmej rano, bo „o siódmej trzeba było budzić dziecko, aby przygotować je do pójścia na godzinę ósmą do szkoły”. Zresztą wkrótce i Profesor musiał iść do pracy rozpoczynającej się o godzinie dziewiątej. Tak systematycznie prowadzona trzygodzinna praca dawała $\mathrm{w}$ roku około tysiąca godzin roboczych. Był to czas wystarczający dla dokonania transkrypcji rękopisu liczącego około 300 stron in folio.

W ten sposób Profesor i jego żona przygotowali do druku cztery wielkie rękopisy. Autorem pierwszego z nich był polski inżynier wojskowy i kartograf Józef Naronowicz-Naroński, który napisał po polsku cztery tomy obszernego, nowoczesnego wówczas podręcznika dla inżynierów wojskowych pod tytułem Księgi nauk matematycznych. Po dwóch latach pracy i czterech korektach monotypowego (ze względu na łatwość wprowadzania poprawek w druku tekstu staropolskiego) składu wyszło jako pierwsze Budownictwo wojenne ${ }^{18}$, stanowiące część trzeciego tomu Ksiag nauk matematycznych.

Rękopis Budownictwa wojennego (formatu $425 \times 315 \mathrm{~mm}$ ), oprawny w pergamin, ukończony został przez Naronowicza-Narońskiego, według informacji umieszczonej na stronie tytułowej, 3 czerwca 1659 roku. Przechowywany był m.in. w zbiorach Tadeusza Czackiego w Porycku, a później w bibliotece Czartoryskich w Puławach. Został skonfiskowany przez władze carskie po powstaniu listopadowym. Wcielony do zasobów Biblioteki Sztabu Generalnego w Petersburgu pod numerem in-

16 Pochodząca z osiadłej na Litwie polskiej rodziny Czepowiczów.

17 Jej praca magisterska (Rozmieszczenie komór celnych i przebieg dróg handlowych na Ślasku do końca XIV wieku) została wkrótce po uzyskaniu przez nią dyplomu, opublikowana we Wrocławiu w 1951 roku jako nr 43 serii A Prac Wrocławskiego Towarzystwa Naukowego. Liczy ona 226 stron i opatrzona jest mapą.

18 J. Naronowicz-Naroński, Budownictwo wojenne. Z rękopisu do druku przygotowata Janina Nowakowa, red. naukowy T. [Marian] Nowak, Prace Komisji Wojskowo-Historycznej MON. Seria B nr 4, Warszawa 1957, ss. XXV, 271. 
wentarzowym 41.171, do Polski powrócił wraz z innymi rewindykowanymi zbiorami na mocy traktatu ryskiego w 1928 roku jako zabytek typu kartograficznego. Włączony został do zbiorów Archiwum Akt Dawnych w Warszawie, a przetrwawszy II wojnę światową, w ramach wymiany trafił w 1950 roku do Biblioteki Uniwersytetu Warszawskiego, gdzie przechowywany jest do dziś pod numerem inwentarzowym 106 . Na zewnętrznej stronie okładki manuskryptu umieszczona jest dziewiętnastowieczna nalepka z napisem „Budownictwo wojenne i pałacowe przez Józefa Naronowicza-Narońskiego 1659”, na grzbiecie zaś znajdują się trzy uszkodzone znaki Biblioteki Sztabu Generalnego w Petersburgu. Wewnętrzna strona okładki posiada ekslibrys tejże biblioteki. Rękopis zawiera ogółem 147 kart, wiele rysunków (wykonanych piórkiem, przeważnie przy użyciu linijki i cyrkla, choć czasem pośpiesznie odręcznie). Zapisany jest głównie czarnym atramentem, aczkolwiek przy niektórych elementach rysunków technicznych, żywej paginie, tytułach i ozdobnikach wykorzystany został atrament kolorowy, czerwony i rzadko zielony ${ }^{19}$.

Dziewięć lat po śmierci Janiny Nowakowej, udało się opublikować przygotowaną z jej pomocą inną część Ksiag nauk matematycznych Józefa Naronowicza-Narońskiego, a mianowicie unikalny natenczas w Europie podręcznik geodezji i kartografii ${ }^{20}$.

Józef Naronowicz-Naroński, arianin, kształcił się najprawdopodobniej w gimnazjum protestanckim w Kiejdanach, założonym w 1625 roku przez Krzysztofa Radziwiłła, gdzie wykładał przez pewien czas Adam Freytag (1608-1650), lub w gimnazjum w Rakowie u Joachima Stegmanna (1595-1633). Na swoich „mistrzów” wskazał w przedmowie do Budownictwa wojennego ${ }^{21}$. Od 1645 roku był w służbie u birżańskich Radziwiłłów, czego ślady zachowały się omawianym rękopisie w postaci mapy i wzmianek o pomiarach tamtejszych terenów ${ }^{22}$.

Omawiany rękopis Kartografii (formatu 370x256 mm) to zbiór notatek, zapisany jedną ręką w XVII wieku atramentem. Dukt pisma jest

19 J. Nowakowa, Wstep, [w:] J. Naronowicz-Naroński, Budownictwo wojenne..., s. V-XXIV.

${ }^{20} \mathrm{~J}$. Naronowicz-Naroński, Kartografia. O delineacyjach miejsc róznych $i$ czynieniu map geographice. Rękopis z 1659 roku do druku przygotowat oraz wstepem i komentarzem opatrzyt Tadeusz Marian Nowak, Białystok 2002, ss. 205.

${ }^{21}$ J. Nowakowa, Wstep, [w:] J. Naronowicz-Naroński, Budownictwo wojenne..., s. VII, XVIII, XXI, XXIII.

${ }^{22}$ Są to m.in. pomiary do mapy Księstwa Birżańskiego, plan Świadości i okolic, mapy Lubecza, Dolatycz, Jaszun, Meracza, Taurogów oraz inne prace kartograficzne dotyczące dóbr radziwiłłowskich. 
niejednorodny, tak ze względu na kształt liter, jak tempo pisma; rozpiętość od pisma starannego i ozdobnego używanego np. przy kaligrafowaniu tytułów, po pośpieszną kursywę (liczne przeróbki i uzupełnienia). We Wstepie do Kartografii... Tadeusz Marian Nowak napisał: „Publikowany zabytek ma dwie cechy charakterystyczne, które wymagały uwzględnienia. Pierwsza polega na tym, że tekst stanowi brulion autorski, zawierający skreślenia, poprawki i dopiski nad wierszem, a także uwagi zamieszczone na marginesach. Sytuacje te zostały zaznaczone i objaśnione w przypisach tekstowych. Drugą cechą jest fakt, że treść publikowanego źródła ma charakter techniczny i w związku z tym ilustrowana jest licznymi rysunkami, tabelami i mapami, którym towarzyszą objaśnienia zastosowanych oznaczeń literowych i symbolicznych. Instrukcja z 1953 ro$\mathrm{ku}$, a także inne przepisy dotyczące publikacji źródeł pisanych nie uwzględniają sytuacji charakterystycznych dla prac o treści technicznej. Poważny problem stanowiło opublikowanie bardzo licznych w tym przypadku rysunków zamieszczonych przez autora w rękopisie. Ze względu na nierozerwalny związek tych rysunków z tekstem narracyjnym zostały one umieszczone - o ile na to pozwoliły warunki techniczne - w tych samych miejscach tekstu, w których znajdują się w rękopisie. Numeracja rysunków oraz dotyczące objaśnienia pochodzące od wydawcy wydrukowana została kursywą. Istniejąca w rękopisie paginacja oddana została w publikacji liczbami umieszczonymi w nawiasach. Braki paginacji objaśniono w przypisach tekstowych”"23. Kończąc Profesor napisat: „Pracę tę poświęcam pamięci mojej żony Janiny Nowakowej, której ofiarna, fachowa pomoc umożliwiła mi przygotowanie tej edycji do druku"24.

Trzecim wielkim manuskryptem, odczytanym i przygotowanym do druku na podstawie porównania trzech zachowanych, równoległych rękopisów ${ }^{25}$, jest podręcznik wiedzy artyleryjskiej napisany po polsku przez Andrzeja dell'Aquę, inżyniera wojskowego, który po ukończeniu weneckiej szkoły artyleryjskiej i służbie na okrętach śródziemnomorskich osiadł w Polsce i tu założył królewską szkołą artyleryjską, dla której przeznaczył swój podręcznik zatytułowany Praxis ręczna działa ${ }^{26}$. Publikacja ta zawiera, oprócz zaopatrzonego w komentarze tekstu, ob-

${ }^{23}$ J. Naronowicz-Naroński, Kartografia..., s. 8-9.

${ }^{24}$ Tamże, s. 9.

${ }^{25}$ Rękopisy z Biblioteki Czartoryskich w Krakowie nr 515 i 1813 oraz Biblioteki Kórnickiej PAN nr 663.

${ }^{26}$ A. dell'Aqua, Praxis ręczna działa. $Z$ rękopisów do druku przygotowal oraz wstępem i komentarzem opatrzył Tadeusz [Marian] Nowak, „Źródła do dziejów Nauki i Techniki”, t. VI, Wrocław-Warszawa-Kraków 1969, ss. 523 (w tym 198 całostronicowych rycin). 
szerny wstęp ${ }^{27}$, aneks w postaci dokumentów związanych z osobą autora i sprawą powstania jego dzieła ${ }^{28}$ oraz komentarz $\mathrm{w}$ formie słownika biograficznego osób wspomnianych przez dell'Aquę ${ }^{29}$, objaśnienia nazw geograficznych, o których jest mowa w podręczniku ${ }^{30}$, bardzo ważnego słownika terminologicznego wyrazów fachowych używanych przez dell'Aquę ${ }^{31}$, a także indeksów osób i nazw geograficznych. Następują po tym krótkie informacje o autorze i jego dziele zredagowane w języku rosyjskim i angielskim.

Czwartym obszernym rękopisem przygotowanym wspólnie do druku jest dokonane przez Macieja Strubicza (ok. 1520-1579) tłumaczenie, na polecenie Zygmunta Augusta (1520-1572), z języka niemieckiego na język polski dzieła Albrechta Hohenzollerna (1490-1568), ostatniego wielkiego mistrza zakonu krzyżackiego i pierwszego księcia pruskiego. Dzieło to zatytułowane w oryginale Von der Kriegsordnung, oder der Kunst Krieg zu führen, a w tłumaczeniu Strubicza Ksiegi o rycerskich rzeczach a sprawach wojennych ${ }^{32}$, wydane zostało w dwujęzycznej i dwutomowej edycji faksymilowej w 2006 roku. Profesor Tadeusz Marian Nowak przeprowadził bardzo staranne studia nad pracą księcia Albrechta ${ }^{33}$; przybliżył historię powstania dzieła, poddał analizie źródła i inne pomoce, $\mathrm{z}$ których korzystał autor ${ }^{34}$, uwzględnił wkład jego pomocników i doradców. O swych współpracownikach Hohenzollern pisał: „Alem też do siebie wezwał inszych ludzi uczonych, którzy wiele języków umieją a około rzeczy a potrzeb rycerskich siła rozumieją i ćwiczeni a świadomi

27 Tamże, s. 5-30.

28 Tamże, s. 31-47.

${ }^{29}$ Tamże, s. 475-482.

30 Tamże, s. 482-488.

31 Tamże, s. 489-503.

32 Por.: J. Nowakowa, Księcia Albrechta Ksiego o rycerskich rzeczach a sprawach wojennych w tlumaczeniu Macieja Strubicza z $1561 \mathrm{r}$., SMHW, 28:1985, s. 72-87.

33 „Praca Albrechta jest dziś bardzo trudno dostępna. Z tekstu oryginału niemieckiego zostały wydane w XIX w.: dedykacja autora dla Zygmunta Augusta, wierszowany wstęp i rozdziały V-VII. Wszystkie te fragmenty znajdują się w publikacjach obecnie bardzo rzadkich. $Z$ tekstu polskiego tłumaczenia Strubicza opublikowano dotąd tylko: dedykację Strubicza, dedykację Albrechta, wierszowany wstęp i spis treści, natomiast właściwy tekst pracy dostępny jest jedynie w rękopisie, ściśle biorąc w dwóch rękopisach: oryginale z 1561 r. i kopii z XIX w. W związku z tym wydanie drukiem Ksiag Albrechta [...] stanowi niewątpliwie rozszerzenie bazy źródłowej dla studiów nad wojskowością XVI w.”. Zob.: T.M. Nowak, Polska wersja „Porzadku wojennego” Albrechta na tle stosunków polsko-pruskich, [w:] Die Kriegsordung des Markgrafen zu Brandenburg Ansback und Herzogs zu Prussen Albrecht des Älteren, Braunschweig, 2006, s. 150.

${ }^{34}$ Wydawca odtworzył dział biblioteki w Królewcu poświęcony starożytnym i nowożytnym dziełom treści wojskowej. 
są, co też około onych starych dziejów przodków naszych sławnych wiele czytali i rozmaitych się rzeczy dowiedzieli i doświadczyli, a z pilnością z nimi, jako się oni starzy Rzymianie i insi sławni a zacni rycerze sprawowali, co za rad, postępków a rozumów w tej i owej rzeczy używali, a co za rycerskie i męskie uczynki czynili rozmawiałem a każdejem się rzeczy gruntownie od nich wywiedzial, teżem $\mathrm{k}$ temu stare i nowe księgi w tych rzeczach i używania i zwyczaje tak stare, jako i nowe z pilnością przepatrzyłem, żeśmy za łaską Pana Boga z tego i z owego nieco zebrali”35.

Książę Albrecht Hohenzollern ukończył pracę przed 10 VIII 1555 roku, kiedy to gotową i podpisaną księgę ofiarował Zygmuntowi Augustowi. Przed jej przekazaniem nakazał sporządzić jej kopie. Jedna z nich, zawierająca na odwrocie karty tytułowej sygnaturę „Georgius Albertus Marchio Brandenburgensis” przechowywana była w berlińskiej bibliotece elektorów brandenburskich i królów pruskich do 1668 roku. Egzemplarz ten nosi tytuł Von der Kriegsordnung, oder der Kunst Krieg zu führen $\mathrm{i}$ jest jedynym zachowanym ${ }^{36}$.

Z kolei tłumaczenie Macieja Strubicza (ukończone 1 VIII 1561 roku, na co wskazuje data dedykacji dla króla Zygmunta Augusta) do 1944 roku zachowane było w dwóch równoległych oryginałach ${ }^{37}$, z których do dziś przetrwał tylko jeden. Nieistniejący już papierowy rękopis (formatu $433 \times 277 \mathrm{~mm}$, spisany jedną ręką kolorowymi atramentami na 601 kartach liczbowanych z licznymi planami, mapami, rysunkami, ozdobnymi inicjałami i ornamentyką o motywach przyrodniczych) pt. Ksiegi o postępkach a sprawach wojennych z pilnościa zebrane i spisane charakteryzował się m.in. zapiskiem na pierwszej karcie ${ }^{38}$ i podpisem Jana Karola Chodkiewicza (1561-1621).

Rękopis ten był w posiadaniu rodziny Chodkiewiczów, potem Sobieskich; Jakub Sobieski (1667-1737) ofiarował go, wraz z całą biblioteką

35 Zob.: T.M. Nowak, Polska wersja „Porzadku wojennego”..., s. 152.

36 Tamże, s. 152.

${ }^{37}$ Nie jest to zresztą przypadek odosobniony, ponieważ w XVI i XVII wieku przed wydrukowaniem, a często zamiast druku, sporządzano kilka egzemplarzy rękopiśmiennych. Tak też było z dziełem Andrzeja dell'Aquy Praxis ręczna działa, zachowanym do 1944 roku w czterech równoległych egzemplarzach.

38 „Roku bożego 1576, dnia 29 Novembris, we czwartek, wilija S. Andrzeja. Na sejmie pierwszym po koronacji J.K.M. w Toruniu posłowie ziemscy z Wielkiego Księstwa Litewskiego nad zmowę, postanowienie i poruczenie braci swej, nie namówiwszy się, ani się zniozszy z Radami Litewskimi, pozwolili i uchwalili ruszenie pospolite na wojnę przeciw moskiewskiemu, skąd temu państwu Wielkiemu Księstwu Litewskiemu pewna zguba i upad. Co dla pamiątki wiecznej z rozkazania jego miłości jest napisano. Fiedor Lastowski”. T. M. Nowak, Polska wersja „Porzadku wojennego”..., s. 153. 
króla Jana III Sobieskiego (1629-1696), bibliotece braci Załuskich. Dokument podzielił los innych załuscianów, został włączony do zasobu Cesarskiej Biblioteki Publicznej w Petersburgu skąd, w drodze rewindykacji na mocy traktatu ryskiego, powrócił do Warszawy w 1930 roku, do Biblioteki Uniwersytetu Warszawskiego. Był, wraz z innymi rewindykatami, przekazany do Biblioteki Narodowej, gdzie zaginął podczas II wojny światowej ${ }^{39}$.

Drugi znany egzemplarz tłumaczenia Macieja Strubicza, także datowany na 1561 rok, to manuskrypt papierowy (formatu 415x285 mm), spisany bardzo starannie, jedną ręką, minuskułą renesansową, przypominającą druk. Posiada podwójną foliację - wcześniejszą (najprawdopodobniej siedemnastowieczną) robioną atramentem (298 kart) oraz późniejszą zrobioną ołówkiem (332 karty). Foliacja ołówkowa nie wykazuje żadnych braków, natomiast atramentowa ma ubytki kart: 137, 138, 287, 288 i 291. Brak tych kart występuje także w kopii ${ }^{40}$ z 1839 roku Kajetana Kielisińskiego (1808-1849), bibliotekarza zbiorów kórnickich Tytusa Działyńskiego, jest więc wcześniejszy niż jej powstanie. Całość tekstu zapisana jest atramentem czarnym, natomiast karty tytułowe ozdobione są barwnymi ornamentami głównie w kolorze niebieskim, czerwonym, zielonym i złotym. Tytuł tego egzemplarza różni się od opisanego powyżej i brzmi Ksiegi o rycerskich rzeczach a sprawach wojennych z pilnościa zebrane a porzadkiem dobrem spisane. Cechą charakterystyczną obiektu był portret księcia Albrechta (karta 10), który został wycięty. Powstałą w ten sposób lukę zaklejono zielonym papierem ${ }^{41}$.

Początkowe losy Księgi o rycerskich rzeczach a sprawach wojennych z pilnościa zebrane a porządkiem dobrem spisane można odtworzyć jedynie hipotetycznie. Pierwotnie rękopis przechowywany był w bibliotece Zygmunta Augusta, później trafił - wraz z częścią jej zasobu - do biblioteki królewskiej Wazów, skąd jako łup wojenny został wywieziony

39 Tamże, s. 153.

${ }^{40}$ Dziewiętnastowieczna kopia przechowywana jest w Bibliotece Kórnickiej PAN pod sygnaturą BK 669. Jest to księga zapisana starannym pismem dziewiętnastowiecznym z bardzo dokładnymi przerysami tablic rysunkowych. Charakteryzuje się tym, że zawiera m.in.: inicjały na kartach: $2,9,11$; tabele na kartach: 78, 79v, 109-110v, 112, 127-130, $237-238 \mathrm{v}$; ryciny po kartach: $152 \mathrm{v}, 153 \mathrm{v}, 154 \mathrm{v}, 155 \mathrm{v}, 156 \mathrm{v}, 157 \mathrm{v}, 161 \mathrm{v}, 162 \mathrm{v}, 163 \mathrm{v}, 164 \mathrm{v}$, $165 \mathrm{v}, 166 \mathrm{v}, 167 \mathrm{v}, 168 \mathrm{v}, 169 \mathrm{v}, 170 \mathrm{v}, 171 \mathrm{v}, 172 \mathrm{v}, 174 \mathrm{v}, 175 \mathrm{v}, 176 \mathrm{v}, 178 \mathrm{v}, 179 \mathrm{v}, 180 \mathrm{v}, 181 \mathrm{v}$, $182 \mathrm{v}, 183 \mathrm{v}, 184 \mathrm{v}, 185 \mathrm{v}, 186 \mathrm{v}, 187 \mathrm{v}, 188 \mathrm{v}, 189 \mathrm{v}, 190 \mathrm{v}, 191 \mathrm{v}, 192 \mathrm{v}, 193 \mathrm{v}, 194 \mathrm{v}, 195 \mathrm{v}, 196 \mathrm{v}$ i na kartach 201-205, 207-211, 216v-217, 218v-219, 220v-221, 222v-223, 224v-225, 226v-227, $228 \mathrm{v}-229,230 \mathrm{v}-231,232 \mathrm{v}-233,234 \mathrm{v}-235$ oraz po karcie $242 \mathrm{v}$; podwojoną numerację rycin 40, 40a . Ponadto niektóre z rycin składają się jedynie z figur i linii geometrycznych, których nie wypełniono barwą i szczegółami. Pomiędzy kartami 173v a 174 jest ślad po wyrwanej rycinie.

41 T.M. Nowak, Polska wersja „Porzadku wojennego”..., s. 154-155. 
w 1655 roku do Szwecji. Do Polski powrócił w XIX wieku za zgodą szwedzkiego króla, Karola XIII (1748-1818). Przywieziony został w listopadzie 1810 roku do Puław przez Felicjana Biernackiego (1775-1852/1853), sekretarza i bibliotekarza ${ }^{42}$ księcia Adama Jerzego Czartoryskiego (1770-1861) ${ }^{43}$. Jako swoje najcenniejsze zdobycze Biernacki wymienił omawiane Księgi o rycerskich rzeczach..., diariusz sejmu piotrkowskiego z 1562 roku oraz metrykę Szczęsnego Kryskiego ${ }^{44}$.

W 1818 roku Łukasz Golębiowski (1773-1849), porządkując puławskie zbiory i opisując poszczególne obiekty, dołączył dość obszerny opis tłumaczenia Macieja Strubicza, lecz bez wiadomości o jego wcześniejszych losach. Fragmenty rękopisu zostały opublikowane w Paryżu w 1858 roku jako Alberti Marchionis Brandenburgensis, ducis Prussiae Libri de arte militari mandato serenissimi regis Poloniae Sigismundi Augusti scripti, nunc primum e codice authentico principis palatini Adami Czartoryski editi. Lutetiae Parisionum, typis L. Martinent $1858^{45}$. Nieistniejący w egzemplarzu z Puław portret księcia Albrechta zastąpiono wizerunkiem Zygmunta Augusta i zmieniono podpis. Wydanie poprzedzone zostało anonimowym wstępem, w którym omyłkowo połączono w jedną historię losy dwóch rękopisów, tego ze zbiorów Chodkiewiczów i tego ze zbiorów Czartoryskich. Błąd ten sprostował dopiero w 1910 roku w J. Korzeniowski w Zapiskach z rękopisów Cesarskiej Biblioteki Publicznej w Petersburgu i innych bibliotek petersburskich ${ }^{46}$.

Podstawę wydania faksymilowego stanowi tekst manuskryptu przechowywany w Bibliotece Czartoryskich w Krakowie. Rękopis ten został - podobnie jak poprzednie - staranie przetranskrybowany i przygotowany do druku przez Profesora Tadeusza Mariana Nowaka i jego żonę. Zainteresowali się nim uczeni niemieccy, m.in. dr Detleft Harms (dawniej związany z Militärgeschichtliches Forschungsamt w Poczdamie), dr Matthias Rogg (podpułkownik), prof. dr hab. Klaus Zimmer (w latach

${ }^{42}$ Feliks Biernacki podjął pierwszą próbę skatalogowania poloników w Szwecji na zlecenie księcia Adama Czartoryskiego. W 1810 roku przybył do Sztokholmu z listem polecającym od jednego z posłów szwedzkich z Petersburga, który umożliwił mu nawiązanie kontaktu z bibliotekarzami, uczonymi i politykami w Sztokholmie, Uppsali i Linköping. Zob. C. Plichowski, $Z$ dziejów szwedzkich zaborów bibliotek i archiwów polskich $w$ XVII i XVIII wieku, „Rocznik Gdański”, 17-18:1960, s. 127-179.

${ }^{43}$ E. Barwiński, L. Birkenmajer, J. Loś, Sprawozdanie z poszukiwań w Szwecji dokonanych z ramienia Akademii Umiejętności, Kraków 1914, s. XV-XVII.

${ }^{44}$ Tamże, s. XV.

${ }^{45}$ Druk w formacie zbliżonym do oryginału $(275 \times 385 \mathrm{~mm})$ zawiera wstęp wydawców, dokładną transliterację tekstu zawartego na kartach 3-41 foliacji ołówkowej.

46 Wydanie w tomie XI „Archiwum do Dziejów Literatury i Oświaty w Polsce”, 1910. 
1998-2008 dyrektor Niemieckiego Instytutu Historycznego w Warszawie), którzy postanowili go wydać wraz z oryginałem niemieckim. Otrzymali więc od profesora $\mathrm{w}$ drugiej połowie lat dziewięćdziesiątych $\mathrm{XX}$ wieku maszynopis oraz wersję elektroniczną przygotowanego do druku tekstu, który po wielu latach opracowywania w końcu ukazał się w 2006 roku.

Niezależnie od przygotowania do druku tych czterech wielkich rękopisów Tadeusz Marian Nowak korzystał w czasie swej pracy z bardzo wielu innych manuskryptów, zawierających z jednej strony traktaty o treści militarnej, a z drugiej liczne akta dotyczące zarówno organizacji wojska, jak i staczanych przez nie walk. Jednocześnie z pracami związanymi z przygotowywaniem do druku i wykorzystywaniem rękopisów prowadził również intensywne badania dotyczące starych druków. Publikację wyników tych badań rozpoczął ogłoszony w 1958 roku artykuł o dawnym polskim piśmiennictwie artyleryjskim ${ }^{47}$, omawiający treść czterech rękopisów i dziewięciu starych druków.

W późniejszej, wydanej w 1961 roku pracy pod tytułem Cztery wieki polskiej książki technicznej ${ }^{48}$, stanowiącej jedyną jak dotąd próbę stworzenia rodzaju podręcznika historii dawnej polskiej literatury technicznej, Profesor zaprezentowal 68 starych druków z lat 1534-1800, reprodukując 79 zaczerpniętych z nich rycin i publikując liczne fragmenty ich tekstów w celu zobrazowania ówczesnego polskiego słownictwa i sposobu przedstawiania treści dotyczących zagadnień technicznych.

W 1961 roku ukazała się inna praca Tadeusza Mariana Nowaka Polskie wojskowe piśmiennictwo techniczne do roku $1764^{49}$, w zapoczątkowanej przez niego w 1953 roku serii wypisów źródłowych, w której wydanych zostało dwanaście tomów. Opracowany przez Profesora tom 8 B stanowią zaopatrzone wstępem objaśniającym obszerne fragmenty prac o treści wojskowej z lat 1547-1743. Są to rękopisy: anonimowy O tajemnicach puszkarskich, Andrzeja dell'Aquy Praxis, Józefa Naronowicza-Narońskiego Budownictwo wojenne i Geometria oraz odtworzone fragmenty zaginionego rękopisu Fryderyka Getkanta, a także stare druki: Marcina Bielskiego, Mikołaja Chabielskiego, Adama Freytaga, Oswalda Krüge-

${ }^{47}$ T. [Marian] Nowak, Przeglad polskiego piśmiennictwa $z$ dziedziny artylerii do potowy XVII w., SMHW, 4:1958, s. 249-276.

${ }^{48}$ T. [Marian] Nowak, Cztery wieki polskiej ksiażki technicznej 1450-1850, Warszawa 1961, ss. 359.

${ }^{49}$ Wypisy zródtowe do historii polskiej sztuki wojennej. Zeszyt osmy B. Polskie wojskowe piśmiennictwo techniczne do roku 1764, oprac. Tadeusz [Marian] Nowak, Warszawa 1961, ss. 235. 
ra, Diego Ufana, Kazimierza Siemienowicza i Wojciecha Bystrzonowskiego. Jeden z tych starych druków, niewielką pracę Oswalda Krügera, Profesor przetłumaczył dla jej uprzystępnienia w całości z łaciny na język polski.

Imponującą ilość dokładnie opisanych 267 pierwszych wydań starych druków oraz trzykrotnie większą ilość ich dalszych edycji i tłumaczeń przedstawił Tadeusz Marian Nowak, będąc redaktorem naukowym i autorem wyczerpującego wstępu do wydania łacińskiego oryginału i polskiego tłumaczenia dzieła Kazimierza Siemienowicza, opublikowanego po raz pierwszy w Amsterdamie w 1650 roku $^{50}$. Sam Wykaz autorów prac przytaczanych przez Siemienowicza w tym wstępie Profesora liczy aż jedenaście stron. Zapoznanie się z taką ilością pogrupowanych tematycznie starych druków stanowiło dla niego - jak sam twierdził - znakomite wprowadzenie do dalszych prac w tym zakresie. Zarówno jego prywatna kartoteka starych druków dotyczących dawnej nauki i techniki, jak i jego wiedza w tym zakresie wzrosły znacznie. Niniejsze wydanie dzieła „eques Lithuanus” 51 składa się z dwóch zasadniczych części: tekstu łacińskiego oryginału i tekstu tłumaczenia polskiego. Przygotowanie do druku tekstu łacińskiego wymagało usunięcia wszystkich błędów drukarskich pierwodruku, częściowo tylko wykazanych w erracie przez Siemienowicza, ujednolicenie systemów skrótów oraz oddania całego tekstu w pisowni łacińskiej obecnie obowiązującej. Tłumaczenie polskie oparte zostało na uprzednio przygotowanym łacińskim, przy czym Profesor starał się w pełni oddać nie tylko treść dzieła, lecz także styl autora.

Prawie w każdej swej pracy Profesor powoływał się na rękopisy, a zwłaszcza stare druki. Niektóre $\mathrm{z}$ tych prac są wręcz im poświęcone. Dotyczy to między innymi artykułu o paralelnym do wcześniejszego artyleryjskiego, przeglądu polskiego piśmiennictwa inżynieryjnego i fortyfikacyjnego ${ }^{52}$.

Rezultatem przestudiowania przez Profesora wielu inwentarzy dawnych polskich bibliotek królewskich, magnackich, szlacheckich, miej-

${ }^{50}$ K. Siemienowicz, Wielkiej sztuki artylerii część pierwsza. Tekst łaciński do druku przygotował oraz tłumaczenia na język polski dokonał Rudolf Niemiec. Redakcję naukową tekstu łacińskiego i tlumaczenia przeprowadził oraz wstęp i komentarz opracował Tadeusz [Marian] Nowak, Warszawa 1963, s. 771.

${ }^{51}$ Pochodzenie Kazimierza Siemienowicza określa zwrot umieszczony na karcie tytutowej.

${ }^{52}$ T. [Marian] Nowak, Przegląd polskiego piśmiennictwa $z$ dziedziny fortyfikacji i inżynierii wojskowej $w$ XVI-XVIII w., SMHW, 11:1965, s. 122-141. 
skich i kościelnych jest jego praca Militaria $w$ bibliotekach polskich $X V I-X V I I$ wieku ${ }^{53}$ zawierająca omówienie bardzo licznych starych druków przechowywanych w tych bibliotekach.

Wzorcowy charakter ma naukowa edycja szesnastowiecznego druku Consilium rationis bellicae hetmana Jana Tarnowskiego (1488-1561) ${ }^{54}$, którego pierwodruk tłoczono u Łazarza Andrysowicza (zm. 1577) w 1558 roku w Tarnowie ${ }^{55}$. Profesor zawarł w niej najpierw notę wydawniczą, wyjaśniając swoje czynności jako edytora, zakończoną podziękowaniem dla żony Janiny. Dalej następuje równolegle wydrukowane: po lewej stronie faksymile kolejnych stron złożonych (poza przedmową) gotycką czcionką, a po prawej ich transkrypcja. Ponieważ przedmowa autorstwa Tarnowskiego napisana jest, w przeciwieństwie do całego dalszego polskiego tekstu po łacinie, Tadeusz Marian Nowak, poza jej fotograficzną reprodukcją oraz prawostronną transkrypcją, podał w komentarzu polski jej przekład. Po edycji całego tekstu następują dwa opracowane przez niego elementy, a mianowicie Komentar ${ }^{56}$ oraz Słownik wyrazów występujących w pracy Jana Tarnowskiego, a obecnie nieużywanych lub używanych w innym znaczeniu, w tym również jednostek miar i monet ${ }^{57}$.

Na ponad 60 starych drukach jako podstawowych źródłach oparta jest praca o rozwoju techniki rakietowej od XIII do połowy XVII wie$\mathrm{ku}^{58}$, przy czym autor nie zawsze korzystał z pierwszych wydań poszczególnych dzieł. Profesor uwzględnił traktaty z zakresu artylerii i pirotechniki, ograniczając się do prac z terenu Europy, nie zajmował się natomiast traktatami powstałymi w kręgu kultury arabskiej i dalekowschodniej. Cezury chronologiczne pracy wyznacza pojawienie się w piśmiennictwie europejskim pierwszych wzmianek o rakietach w drugiej

${ }^{53}$ T. [Marian] Nowak, Militaria w bibliotekach polskich XVI-XVII wieku, [w:] Polskie biblioteki wojskowe 1767-1967. Ksiega pamiatkowa 200-lecia polskich bibliotek wojskowych. Materiały sesji naukowej odbytej w dniach 9-11 X 1967 r., red. nauk.: J. Lewicki, T. Peterson, Warszawa 1969, s. 77-99.

${ }^{54} \mathrm{~J}$. Tarnowski, Consilium rationis bellicae. Wstęp napisał Janusz Sikorski. Tekst dzieła do druku przygotował oraz notą wydawniczą, komentarzem i słownikiem opatrzył Tadeusz Marian Nowak, Warszawa 1987, ss. 206.

55 Pierwsze wydanie (formatu 220x140 mm) obejmuje 9,5 arkusza druku. Karta tytułowa i przedmowa wybite zostały antykwą renesansową (A-A II) na 0,5 arkusza. Tekst właściwy wydrukowany został szwabachą na 9 arkuszach, których składki sięgają od A do I, a każda czwarta karta jest niesygnowana. Zob. tamże, s. 27-31.

56 Tamże, s. 180-192.

57 Tamże, s. 193-205.

58 T.M. Nowak, Rozwój techniki rakietowej w świetle traktatów XIII-XVII wieku, „Rozprawy z Dziejów Nauki i Techniki”, t. 4, Warszawa 1995, ss. 264. 
połowie XIII stulecia w Liber ignium ad comburendos hoste (Ksiega ogni dla spalenia nieprzyjaciót) Marcusa Graecusa ${ }^{59}$ oraz ukazanie się drukiem w połowie XVII wieku Artis magnae artilleriae pars prima Kazimierza Siemienowicza, której księga trzecia stanowi pewnego rodzaju podsumowanie dotychczasowego dorobku w tej dziedzinie ${ }^{60}$. Precyzyjna interpretacja treści tych dawnych książek, zawierających przede wszystkim traktaty artyleryjskie, umożliwiła odtworzenie nieznanych dotąd w tak pełnym zakresie danych o europejskiej technice rakietowej tych wczesnych czasów. Dokładna bibliografia wykorzystanych dzieł uwzględnia nawet sygnatury biblioteczne egzemplarzy, z których korzystał autor. Nowością jest przy tym, obok indeksów nazwisk i nazw geograficznych, Indeks rzeczowo-terminologiczny ${ }^{61}$, uwzględniający nazwy omówionych w pracy elementów technicznych w języku staropolskim i w czterech językach europejskich: łacińskim, francuskim, niemieckim i włoskim.

Pracą, na którą chciałabym jeszcze zwrócić uwagę, jest bibliografia wydanych drukiem do końca XVI stulecia traktatów dotyczących fortyfikacji ${ }^{62}$. Dążąc do stworzenia pełnego obrazu, Tadeusz Marian Nowak - jak sam mówił - starał się zebraćc ${ }^{63}$ komplet odnośnych druków, a równocześnie podać każdorazowo zwięzłe dane dotyczące autora i jego dzieła lub dzieł - z podaniem ich tytułów, wydań i tłumaczeń. Omówił w ten sposób 46 autorów i 129 tytułów oraz 215 wydań. Przy każdym autorze podana jest bibliografia wzmianek o nim, a przy jego dziełach oprócz standardowych danych bibliograficznych - miejsca przechowywania egzemplarzy. Nowością - wymagającą według mnie wyraźnego za-

${ }^{59}$ Tekst Księgi ogni... w zachowanej do dziś postaci powstał w latach 1250-1300, wykorzystywany był przez wielu autorów. Zawierał m.in. treści dotyczące rodzajów rakiet (np. swobodnie wznoszących się górę, jednostopniowych i podwójnych), opis przyborów niezbędnych do ich produkcji, opisy powłoki rakietowej, charakterystykę używanego paliwa (np. paliwo oleiste, paliwo suche), jego ładowanie, a także budowę głowicy, konstrukcję wyrzutni, zapalników oraz praktyczne zastosowanie rakiet. Praca Marka Greka po raz pierwszy ukazała się drukiem w 1804 roku w Paryżu. Tamże, s. 21-47.

${ }^{60} \mathrm{~W}$ Zakończeniu czytamy: „Właściwe podsumowanie pierwszych czterech wieków rozwoju europejskiej myśli technicznej w dziedzinie techniki rakietowej stanowi dzieło Kazimierza Siemienowicza [...]". Tamże, s. 221.

61 Tamże, s. 242-250.

${ }^{62}$ T. M. Nowak, Europejskie traktaty fortyfikacyjne wydane drukiem do końca XVI wieku. Przeglad bibliograficzny, SMHW, 38:1996, s. 53-96.

63 Profesor kompletował swoją kartotekę przez ponad 40 lat. Odnotował - zdaje się wszystkie - wydane w latach 1472-1600 europejskie druki dotyczące najogólniej pojętej techniki wojskowej, a więc przede wszystkim artylerii i inżynierii wojskowej, w której skład wchodzą m.in. fortyfikacje stałe i polowe oraz kartografia wojskowa. 
akcentowania - jest załączenie tabel ukazujących w sposób poglądowy: autora, tytuły i daty wydań jego dzieł oraz miejsca ich przechowywania w dziewięciu polskich ${ }^{64}$ i trzech zagranicznych ${ }^{65}$ bibliotekach.

Podczas jednego z naszych spotkań Profesor powiedział mi, że chciałby kontynuować ten kierunek pracy i pokazał mi kartotekę dzieł dotyczących fortyfikacji powstałych w następnym stuleciu. Jest ona znacznie większa od tej, która obejmuje dzieła XVI wieku. Mam nadzieję, że teraz będzie ona użyteczna dla innych historyków wojskowości, a wysiłek profesora Tadeusza Mariana Nowaka zgrupowania w jednym miejscu całości siedemnastowiecznego piśmiennictwa nie będzie daremny.

Następną pracą opartą na starych drukach jest zestawienie europejskich dzieł treści wojskowej, przetłumaczonych na język polski i opublikowanych w Rzeczypospolitej do końca XVIII wieku ${ }^{66}$. Chodzi tu w sumie o 46 oryginałów obcojęzycznych i taką samą ilość tłumaczeń oraz o sporą liczbę starych druków odgrywających tu rolę pomocniczą. Lącznie autor omówił w tej pracy 160 starych druków, podając przy tym sygnaturę biblioteczną każdego z nich. Poza tą statystyką - co chciałabym podkreślić - praca zawiera ogromną ilość wiadomości zarówno o autorach, tłumaczach i wydawcach, jak i przede wszystkim o treści ich dzieł.

Również w 2000 roku ukazała się inna jeszcze praca, której treść stanowi omówienie źródeł, na których uczony jezuita Franciszek Paprocki (1723-1805) oparł swoje, wydane w 1776 roku, pierwsze w literaturze naukowej dzieło o historii wojen i wojskowości polskiej ${ }^{67}$. Źródłami tymi były oczywiście stare druki. Sposobność do omówienia jeszcze większej liczby dawnych druków dało Profesorowi bliższe zajęcie się warszta-

${ }^{64}$ Są to: Biblioteka Narodowa, Centralna Biblioteka Wojskowa, Biblioteka Uniwersytetu Warszawskiego, Biblioteka Publiczna m.st. Warszawy, Biblioteka Uniwersytetu Wrocławskiego, Biblioteka Jagiellońska, Biblioteka Zakładu Narodowego im. Ossolińskich we Wrocławiu, Biblioteka Uniwersytetu Mikołaja Kopernika, Biblioteka Gdańska PAN.

${ }^{65}$ Są to: Bibliothèque Nationale w Paryżu, British Library oraz ujęte w łącznym katalogu biblioteki USA i Kanady.

66 T.M. Nowak, Polskie tlumaczenia europejskiej literatury wojskowej, dokonane $w X V I-X V I I I$ wieku, „Rozprawy z Dziejów Nauki i Techniki”, t. 10, Warszawa 2000, ss. 184. W tym miejscu chciałabym wspomnieć, iż była to pierwsza praca profesora, z którą się zapoznałam będąc jeszcze na studiach i zajmując się warszawską drukarnią Księży Misjonarzy św. Wincentego á Paulo, która wydrukowała między innymi książkę Józefa Jakubowskiego Nauka artylerii (t. 1-3, 1781-1783), uważaną przez profesora Tadeusza Mariana Nowaka za pierwsze obszerne dzieło o artylerii w języku polskim, po wydanym w 1643 roku tłumaczeniu hiszpańskiej pracy Diego Ufano Archelia .

${ }^{67}$ T.M. Nowak, Księdza Franciszka Paprockiego SJ praca o historii wojen $i$ wojskowości polskiej wydana w 1776, „Analecta..., 2:2000, s. 135-172. 
tem pracy księdza Paprockiego ${ }^{68}$, który posługiwał się znaczną ilością wcześniejszych dzieł starożytnych, średniowiecznych, a zwłaszcza nowożytnych. Studium to znalazło się w zbiorowym tomie obok artykułu dotyczącego działalności Józefa Rogalińskiego SJ (1728-1802) ${ }^{69}$.

Jedną z ostatnich praca Profesora, w pełni „starodruczną”, jest opracowanie Stare druki Biblioteki Muzeum Wojska Polskiego w Warszawie, zamieszczone w tomie jubileuszowym „Studiów i Materiałów do Historii Wojskowości" "70. Autor wykazał, że biblioteka warszawskiego Muzeum Wojska Polskiego posiada 550 dawnych druków, które nie zostały jak dotąd skatalogowane, a jedynie spisane dla celów porządkowych. Profesor sporządził dla własnych celów naukowych katalog kartkowy, wybiórczy, zawierający najważniejsze według niego pozycje. Podzielił je rzeczowo i omówił w artykule dwa pierwsze ich działy. Pierwszy z nich obejmował zachodnioeuropejskie traktaty i podręczniki wojskowe w podziale rzeczowym na: prace dotyczące wojska w starożytności; prace dotyczące wojska czasów nowożytnych ${ }^{71}$. Natomiast drugi dział uwzględniał polskie piśmiennictwo wojskowe, na które składały się prace napisane po polsku i prace tłumaczone na język polski. Łącznie przebadał 95 dzieł, które uznał za najważniejsze.

W 2008 roku Wydawnictwo DiG opublikowało De bona militum valetudine conservanda liber Antona Schneebergera (1530-1581), lekarza, bibliofila, posiadacza bogatej biblioteki, w której obok dzieł z zakresu medycyny, nauk przyrodniczych były liczne humaniora. Na uwagę zasługuje fakt odnotowania w jej zasobie traktatu Andrzeja Frycza Modrzewskiego O poprawie Rzeczypospolitej oraz egzemplarza pierwszego wydania Mikołaja Kopernika De revolutionibus orbium coelestium ${ }^{72}$. Przy tej edycji Profesor udzielał licznych konsultacji oraz przygotował notę wydawniczą.

68 T.M. Nowak, Warsztat pracy Franciszka Paprockiego SJ pierwszego tlumacza na jezzk polski dzieta Wegecjusza o wojskowości rzymskiej, [w:] Wkład jezuitów do nauki i kultury w Rzeczypospolitej Obojga Narodów i pod zaborami, pod redakcja naukową I. StasiewiczJasiukowej, Kraków-Warszawa 2004, s. 357-384.

69 T.M. Nowak, „Prawidta catej sztuki wojennej” w ujęciu Józefa Rogalińskiego SJ z 1776 roku, [w:] Wktad jezuitów do nauki i kultury..., s. 339-356.

${ }^{70}$ SMHW, 44:2007, s. 15-39.

${ }^{71}$ A te na: prace ogólne; prace dotyczące fortyfikacji; prace dotyczące artylerii; prace dotyczące piechoty; prace dotyczące kawalerii.

72 A. Schneeberger, De bona militum valetudine conservanda liber = Ksiega o zachowaniu dobrego zdrowia żolnierzy, edycja tekstu łacińskiego i przekład R.A. Sucharski, wstęp, indeksy i redakcja całości S. Ilnicki, przypisy S. Ilnicki i R. A. Sucharski, nota wydawnicza T. M. Nowak, Warszawa 2008, s. XI-XII. 
Mam nadzieję, że w przedstawionych przeze mnie pracach na polu edytorskim prof. dr. hab. Tadeusza Mariana Nowaka zdołałam oddać to, że ,[...] dzieje nauki to również biografie uczonych, w owych biografiach zaś do najciekawszych chyba rodzajów należą te, które dotyczą sui generis narodzin uczonego, a więc tego okresu - a czasem nawet i momentu - kiedy po raz pierwszy zarysowało się jego powołanie życiowe i kiedy zaczyna się kształtować jego przyszła kariera naukowa” (Juliusz W. Gomulicki).

\section{Summary \\ Professor Tadeusz M. Nowak and His Activities in the Field of Publishing Historical Source Materials}

Tadeusz Marian Nowak (1917-2010) was an outstanding researcher in thefields of Polish military history, cartography, and a keen editor of manuscript and old printed materials relevant to these disciplines. His research was characterised by wide horizons and an interdisciplinary approach. Within his chief specializations one finds Polish and European military engineering and technology. He was deeply convinced that publishing of primary source materials is very important from the point of view of their accessibility and preservation. His editions demonstrate the perfectionist attitude he always demanded from himself and his collaborators. Tadeusz M. Nowak also authored numerous monographs, not to mention translations from the Latin, German, French, Dutch, and Russian. His complete bibliography numbers over 300 items. 